\title{
BENEFITS UNDER THE INCOME TAX ACT
}

\author{
FRANK D. JONES*
}

The Department of National Revenue, realizing that the more "fringe benefits" a person receives the less taxable income he requires in order to maintain the same standard of living, has inserted sections in the Income Tax Act aimed at taxing such "benefits." In this article Professor Jones examines the effect of the wording of sections 5 and 16 on the taxability of such "benefits".

As Lancelot J. Smith in his article "Tax Position of Fringe Benefits"1 points out:

Generally speaking the executive is more interested in fringe benefits than his present take home pay. He is deeply conscious of the impact of personal income tax rates and so is usually quite susceptible to inducements which will provide the security which he seeks and at the same time ease the tax burden on himself.

The more "benefits" a person receives (particularly of the nontaxable type) the less taxable income he requires in order to maintain the same standard of living. If, for example, a company supplies a house for its employee, this alleviates the necessity of the individual expending after tax dollars in order to purchase such a house, and at the same time his standard of living is maintained. Indeed, the dollars so freed may be used by the individual to raise his level of living and such dollars are "freed" each year by virtue of the fact that he does not have a large fixed annual expense (i.e. mortgage) relating to the house.

The Department of National Revenue, of course, is well aware of such advantages and there are interspersed in the Income Tax Act ${ }^{1 \mathrm{a}}$ several sections endeavoring to tax such "benefits." Sections 5, 8 (1), 16 (1), 81 (1) and 137 (2) are examples of such legislation. Section 8 has been the subject of several excellent articles and comments ${ }^{2}$ and I propose to show the breadth and some limitations relating to section $\mathbf{5}$ and section 16.

It should be kept in mind that even though the "benefit" is in fact taxed, the individual so taxed must only expend the actual dollars required to meet the tax liability which normally will not amount to more than $50 \%$ of the value of "benefit" so conferred depending upon the individual's personal income tax rate. This results in the person obtaining the enjoyment of the "benefit" while paying only a portion of its worth.

The more popular "benefits" are:

(1) Pension Plans

(2) Profit Sharing Plans

(3) Stock Options

(4) Retiring Allowances

(5) Death Benefits

(6) Deferred Compensation Plans

- B.A. (Alta.), LL.B. (Dal.), LL.M. (Tor.) Associate Professor, Faculty of Law. The University of Alberta.

11959] Corporate Management Conference, 59

1a Income Tax Act, R.S.C. 1952, c. 148 as subsequently amended. Hereinafter referred to as I.T.A.

2 McIntosh \& Patterson. The Long Reach of Section 8, [1963] 2 Can. Tax. J. 94; Turnbull Section 8 (1) and Incorporation [1964] 1 Can. Tax. J. 26; Turnbull, Section 8 (1) and The Parker Case, [1966] 4 Can. Tax J. 321. 
In considering these "benefits" three main questions arise:

1. May a company write off the cost of such a "benefit"?

2. Is the cost of the "benefit" as paid by the company, taxed as part of the employees income?

3. Is the "benefit" taxed when paid to the employee or his dependent or his estate?

The criteria of deductibility is spelled out in sections 12 (1) (a) and 12 (1) (b) with the general criteria being that the expense must be incurred by the taxpayer for the purpose of gaining or producing income and must not be a capital expense in order to be deductible. A further limitation as to the deductibility is found in section $12(2)$ wherein the expense must be "reasonable in the circumstances" in order to be deductible. The purpose of this paper is not to discuss deductibility but to attempt to enumerate and examine the types of benefits which are taxed together with some limitations on taxability.

It would be useful initially to attempt to define what is meant by the terms "benefits," "advantage," and "appropriate." Black's Law Dictionary, Fourth edition 1961 which has been used as authority by Canadian Tax Courts" defines "advantage" as: "Any state, condition, circumstance, opportunity or means specially favorable to success, prosperity, interest, reputation, or any desired end." Webster's New International Dictionary (1954) defines "advantage" as "any condition, circumstance, opportunity or means particularly favorable to success, or to any desired end."

The word "benefit" is defined in Black's Law Dictionary as meaning "a pecuniary advantage of profit; gain; account; interest." Webster's New International Dictionary defines "benefit" as meaning "to advance." The word "appropriate" is defined in Black's Law Dictionary as meaning "to prescribe a particular use for particular moneys; to designate or destine a fund or property for a distinct use, or for the payment of a particular demand." Webster's New International Dictionary defines the word "appropriate" as meaning "to set apart for or reassign to a particular purpose or use in exclusion of all others."

There have been several judicial definitions relating to these words. Some of these definitions relate to cases the issues of which did not pertain to tax or taxation matters.

Re Levy" defines "appropriate" as meaning "to exercise dominion over property to the extent and for the purpose of making it subserve one's own proper use and pleasure." Re Sommerville" states: "Appropriate in its ordinary acceptation means to set apart for or assign to a peculiar purpose, person or use to the exclusion of others."

It is interesting to note that the definition contained in Re Levy implies that the person for whom the property is appropriated must make the appropriation. In the definition contained in Re Sommerville ${ }^{6}$ a third party may "appropriate" for another person. In my opinion it is this latter definition which would be applicable in a tax situation.

It should be noted that in order to come under the Income Tax Act the benefit must be "taxable." This then implies that it must be some-

\footnotetext{
3 Sim v. M.N.R.; [1966] C.T.C. 383; 66 D.T.C. 5276 [Ex. Ct.].

4 Re Levy (1924), 26 O.W.N. 300, 301.

5 Re Sommerville (1926), 31 O.W.N. 289, 290.

$\rightarrow$ Ibid.
} 
thing that in fact can be valued since the act itself speaks of the value of benefits received or enjoyed. This idea has been judicially expressed in both England and the recent Canadian case Bourque v. M.N.R. ${ }^{7}$ wherein $\mathrm{Mr}$. Boisvert states:

The section invoked by the respondent is to be construed as meaning that if an advantage is conferred it must be apparent, real, tangible at the time of assessment. The benefit must have a moneys worth and be capable of realization into cash.

A word of caution should be introduced here in applying English cases to the Canadian tax scene due to the fact that the English Finance Act is narrower in its scope than is the wording under the Canadian Income Tax Act and therefore cases escaping taxation in England may not necessarily escape tax in Canada.

It is seen that Mr. Boisvert uses "advantage" and "benefit" interchangeably. I suggest, however, that the difference between an "advantage" and a "benefit" is that an "advantage" has as part of its character an enduring aspect. An "advantage" may confer no immediate "benefit" but may put one in the position to reap a "benefit" sometime in the future. These words should not be used interchangeably due to the fact that the Income Tax Act itself speaks of "benefit" or "advantage"s thereby connoting a distinction. In the area of benefits, Canadian Tax Courts have generally taken the view that the benefit has not been conferred until it is actually received. In this sense the word "appropriate" would seem to denote an actual receipt by the beneficiary and not some future allocation out of which nothing of value is obtained in the present taxation year. I would suggest that it should be likened to the idea that benefits are taxed on a cash basis.

Turning now to sections 5 and 16 taking them in numerical order.

\section{SECTION 5}

Section $\mathbf{5}$ of the Income Tax Act in part reads as follows:

(1) Income for a taxation year from an office or employment is the salary, wages or other remunerations, including gratuities, received by the taxpayer in the year plus

(a) The value of board, lodging and other benefits of any kind whatsoever (except the benefits he derives from his employer's contribution to or under a registered pension fund or plan, group sickness, or accident insurance plan, medical services plan, supplementary unemployment benefit plan, deferred profit sharing plan or group term life insurance policy) received or enjoyed by him in the year in respect of, in the course of, or by virtue of the office or employment; ....

\section{Identifying a Benefit}

In ascertaining what type of "benefits" fall within the statutory enactment of "other benefits of any kind whatsoever" it should be noted that only benefits by virtue of the taxpayer's position as employee are normally taxed in the hands of the recipient. A valid gift not related to a person's occupation does not of course fall within section 5 . It is often very difficult to ascertain when a gift falls outside of section 5 and when a gift is given due to the fact that the person is an employee. In many cases what appears to be a gift possesses an element of reward for services and this element may be sufficient to stamp the apparent gift as income. The distinction between award for service and a mere 
recognition of service was exhaustively discussed in Seymour v. Reed ${ }^{9}$ wherein the appellant was the professional cricketer and in the service of a cricket club and the committee of the club in the exercise of an absolute discretion granted him a benefit match. The proceeds of the match together with public subscriptions were invested in the names of the trustees of the club and the income therefrom was paid to the appellant in accordance with the rules of the club. Subsequently the investment was realized and proceeds paid over to the appellant who applied them with the approval of the trustees in purchasing a farm.

In deciding that the proceeds in question were not taxable as income Rowlatt, J., applied the test-is it in the nature of a personal gift or is remuneration? The judgment was reversed by the Court of Appeal but restored by the House of Lords. In approving the aforementioned test Viscount Cave, L. C., stated:

A benefit is not usually given early in a cricketer's career but rather towards its close in order to provide an endowment for him on retirement. Its purpose is not to encourage the cricketer to further exertions but to express the gratitude of his employers and the cricket-loving public for what he has already done and their appreciation of his personal qualities. . . . The whole sum-gate money and subscriptions alike -is a testimonial and not a prerequisite. In the endthat is to say when all the facts have been considered-it is not remuneration for services but a personal gift.10

This question has troubled English courts for a considerable period and there are a great many cases relating to this point. ${ }^{11}$ In Denny v. Reed $^{12}$ Finlay, J., stated:

The survey of those cases shows that questions of considerable difficulty may arise in cases of this sort, the difficulty being to draw the line between what is a mere present or testimonial on the one hand and what must be regarded as a prerequisite for profit of the office on the other. It is perfectly clear that the circumstance that a payment was a voluntary one is in no way decisive of the questions. There are plenty of voluntary payments which are assessable to income tax when they are paid. An important test, I think, is whether the sum is paid after the conclusion of the office or while it was going on, and the importance of that is well seen by looking at Lord Sterndale's judgment in Cowan v. Seymour. Another important test is whether the sum was paid by the employer or by somebody else. None of these is absolutely decisive, but these are matters which are of importance.

The contrast between a personal gift and remuneration is well exemplified in Atkinson's, J., judgment in Calvert v. Wainwright ${ }^{13}$ which turns upon the assessability of tips given to a taxi-driver:

The ordinary tip given in those circumstances would be something which would be assessable, but supposing at Christmas, or when a man is going for a holiday, the hirer says: 'you have been very attentive, here is a $£ 10$ note,' he would be making a present, and I would say it would not be taxable ...14

There have been various cases with respect to testimonials to employees, clergymen, and the like, and in each the test is whether the benefit is received as a personal testimonial or as a result of their faithful service. A benefit must be paid by virtue of his being an employee in order to be taxable. As was stated in Hunter v. Dewhurst ${ }^{15}$ the "causa causans" for the payment must have been his status as employee.

9 [1927] A.C. 554 .

10 Id., at 559 .

11 A representative selection is as follows: Cowan v. Seymour (1919), 7 T.C. 372; Mudd v. Collins (1925), 9 T.C. 297; Beynon v. Thorpe (1928) 14 T.C. 1; 'stedeford v. Beloe (1932), 16 T.C. 505 .

12 (1933), 18 T.C. 254, 258.

13 1947] 1 K.B. 526.

14 Id. at 528 .

16 (1932) 16 T.C. 605. 
It is often very difficult to determine whether a person is an employee or not. The best expression of the problem $^{16}$ is to attempt to ascertain whether an amount received by an individual is under an express or implied contract for service which would count as remuneration to an employee or whether it is received under an express or implied contract for services and thus would represent a business or profession. The question depends on whether or not a master-servant relationship exists between payor and payee. That this is a question of fact which must be determined according to the evidence adduced in each case is rather pointedly brought out in Abrahams v. M.N.R. ${ }^{17}$ where, despite an admission by the counsel for the Minister of National Revenue that the taxpayer was not an employee, Mr. Justice Jackett finds otherwise. The President stated:

I might make this comment, however, that a discussion of these issues assumes an air of fantasy and unreality when all the evidence points to the conclusion that the appellant directed the operation of the sales organization that I referred to earlier as an employee of the company while the appellant takes the position, and the respondent concedes, that he did so as an independent contractor. In these circumstances, it would seem that this might be a case where the evidence and the admission made by counsel for the Minister cannot stand together, in which event, the admission should be taken to be made under a misapprehension and it is the duty of court to have regard to the real facts as shown by the evidence. ${ }^{18}$

One of the best statements of the criteria relating to a determination as to whether an individual is under a master-servant relationship is found in DiFrancesco v. M.N.R. ${ }^{19}$ where Mr. Fordham quoting from Halsbury's Laws states:

A servant (employee) acts under the direct control and supervision of his master, and is bound to conform to all reasonable orders given him in the course of his work; an independent contractor, on the hand, is entirely independent of any control or interference, and merely undertakes to produce a specified result, employing his own means produce that result. ...

To distinguish between a contractor and a servant (employee), the test is whether or not the employer retains the power, not only in directing what work is to be done, but also of controlling the manner of doing the work. ${ }^{20}$

One of the key words to be noted is the word "power". So long as an employer has the power to direct the employee it matters not whether in fact this power is used.

The courts are more reluctant to classify a professional person as an "employee" than a non-professional person. Thus, in Bell v. M.N.R. ${ }^{21}$ a physician contracted to carry out medical work in an industrial plant for a number of companies. Even though there was in fact a written contract, income received by the taxpayer from the companies was held not to be income from office or employment. A part-time dental lecturer at the University of Toronto ${ }^{22}$ and a hospital pathologist ${ }^{23}$ were both held not to be "employees" within the meaning of the act.

In contrast a fuller brush salesman ${ }^{24}$ and an encyclopedia salesman ${ }^{25}$ were held to be employees within the meaning of the act even though

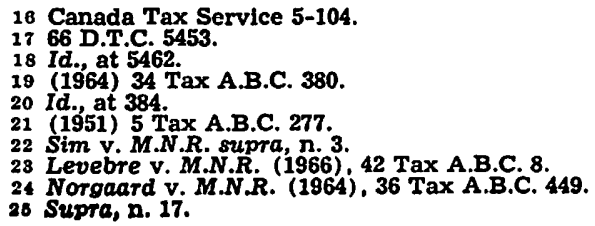


in both instances they were given virtual control to run their respective territories in any manner they saw fit.

As stated previously the differentiation is a vital one with respect to section 5 in that if a taxpayer is not classified as an "employee" section 5 (1) (a) has no revelence and therefore "benefits of any kind whatsoever" would not apply to amounts received.

Section 139 (1) (1) defines "employed" as meaning "performing the duties of an office or employment." In England it has been held that the position of a director of a company fulfills this definition. This was the position at English Common Law and has been codified by section 161 (3) of the English Finance Act. It is, in my opinion, debatable whether or not Canadian courts would follow this concept and hold that by simply being a director of a company one was "employed" with the result that the benefit provision of section 5 would apply. I submit that this contention is supported in that draftsmen of the Income Tax Act deemed it necessary to specifically include directors salaries or fees as income in section 6 (1). If by virtue of their office or position as director they were "employed," such fee or salaries would be included in section 5 and would alleviate the necessity of the specific inclusion under section 6 (1).

Turning now to the types of "benefits" which are taxed under section 5 , there are a myriad of reported cases ${ }^{26}$ with respect to this area and I shall attempt here only to give a brief resume of the type of benefit which has been subject to litigation. Probably the most familiar benefit is the personal use of a company's car by its employee. In essence the private use of the automobile by the employee is deemed to be a benefit and therefore taxable. A non-assignable short term option to purchase shares at less than the market value was exercised by an employee and the difference between the purchase price and the market value was taxable under section 5 (1) (a). ${ }^{27}$ The president of a company who occupied a furnished apartment, the rent of which was paid by the company, had to include in his income the rental payments made. ${ }^{28}$ The position of whether strike pay is a "benefit" is an interesting one. A letter from the Department of National Revenue dated March 20th, 1956 states:

The position of strike pay or benefits depends on whether they can be regarded as income from an office or employment. This in turn depends upon the exact terms of the agreement between the union and its members.

It is submitted therefore that we are thrown back on the concept of whether or not the union member is an employee within the context discussed previously, and if so the benefits will be taxed.

In Foley v. M.N.R. ${ }^{29}$ the appellant was one of the vice-presidents of a liquor company with its head office in Montreal. He resided in Vancouver and was covered under the British Columbia hospital plan. On a trip to the head office he became ill and spent about a month in a

\footnotetext{
20 A selected sample of which is as follows:

Nourse v. M.N.R., 61 D.T.C. 139;

Turnet v. M.N.R., 66 D.T.C. 415;

Curtis v. M.N.R., 57 D.T.C. 509 ;

Curtis v. M.N.R., 57 D.T.C. $509 ;$
Ravary v. M.N.R., 62 D.T.C. $14 ;$

Ravary v. M.N.R., 62 D.T.C. 14;

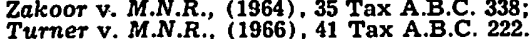

27247 v. M.N.R., 55 D.T.C. 192.

2x Cockrill v.M.N.R., 65 D.T.C. 525.

בט 65 D.T.C. 20.
} 
Montreal hospital. His hospital bill, after deducting the payment under the provincial plan, amounted to $\$ 757.00$ which included a number of charges which he would not have had to pay personally had he been hospitalized in British Columbia. The appellant discussed the situation with the company that employed him and it was agreed that he should include $\$ 529.00$ of his hospital bill in his expense account for his trip to Montreal. The minister added the $\$ 529.00$ to the appellant's reported income as a "benefit" conferred on him by his employer within the meaning of Section 5 .

\section{Mr. Davies stated:}

However, in the light of all facts, there would appear to be very good reason for regarding the payment of $\$ 529.65$, not as a benefit the value of which is to be ascertained and taxed under paragraph of (a) subsection (1) Section 5 of the Income Tax Act. ${ }^{30}$

He then went on, however, to say that it was taxable under section 5 (b) as an allowance for personal or living expenses. It is submitted that this case highlights an essential idea with respect to the taxation of benefits. A benefit in order to be taxed must confer upon the recipient something which increases his net worth at the time the benefit was conferred. No taxable benefit is conferred by a simple repayment or reimbursement which in effect simply leaves the recipient in the same position as when he started. Let me hasten to add that certain "allowances" are taxed under Section 5 which are simply reimbursements of monies expended. However, it is my contention that these are not taxable "benefits" within the meaning of the Income Tax Act. This idea is supported in the case of $M r$. L. v. M.N.R. ${ }^{31}$ wherein an employee took a special course for which he paid a fee. It was understood that upon successful completion of this course his employer would refund his fee with a bonus. The refund and bonus were paid. The employee included the bonus in his income but not the refund of the fee. It was held that the refund was not income.

Payment of an amount upon dismissal from employment has been held to be taxable as a benefit under section 5 (1) (a). In Buchanan v. M.N.R. ${ }^{32}$ an amount was received by $\mathrm{Mr}$. Buchanan on his dismissal from the firm of solicitors that had employed him in Calgary. The Exchequer Court agreed that the payment was a gift in the sense that the legal firm was under no obligation to pay it but stated the payment was liable to tax even though it was voluntary on the part of the person who made it. The payment was identical to three months pay and the court found it impossible to escape the conclusion that the payment was intended to be remuneration rather than a gift personal to the appellant. It therefore found the payment to be a "benefit" received by him "in respect of, in the course of, or by virtue of the office or employment" within the meaning of section 5 (1) (a). In reviewing the authorities, including Seymour v. Reed,,$^{33} \mathrm{Mr}$. Justice Cattanach stated:

I take the question to be whether the payment is in the nature of a personal gift or is it in the nature of remuneration. In this sense the word "personal gift" is used in contra-distinction to remuneration. Therefore to say that a payment was intended as a personal gift is merely to say that it was not intended to be

30 Id., at 22.

31 50 D.T.C. 3477.

3266 D.T.C. 5257 .

33 Supra, n. 9. 
remuneration. ... The amount paid was identical to three months pay in lieu of notice. It was treated by the firm as remuneration and I cannot escape the conclusion that it was intended as such rather than a personal gift to the appellant.84

If the decision had stopped there, there would be nothing too startling in its result. However, at the end of the case there is one sentence of which any tax planner should be aware. Mr. Justice Cattanach stated:

Neither do I think the fact that the appellant's employment had been terminated when the payment was made prevents the payment from being taxable income. ${ }^{3}$

If the learned Justice means by this statement that the income is taxable under Section 5, which is in fact the section used in the case, the ramifications of his thinking are great indeed. Mr. Justice Cattanach after making the aforementioned statement says "see Cowan v. Seymour"." The issue in Cowan v. Seymour was whether or not a payment received by a liquidator of a company, who served in this capacity without remuneration after the winding up of the company was complete, was a payment pursuant to his employment. It was held by the Court of Appeal per the Master of the Rolls and Lord Justice Atkin that such a payment was not taxable. The Master of the Rolls stated:

Therefore I do not think that proposition can be maintained. But the fact that the office is at an end is a fact of very, very great weight, and when you add to that, that the payment is made, not by the employer, because it was not made and could not be made here by the company, which was the employer, but is made by another person-in this case it was made by the shareholders individually-the facts still point more to it not being a payment for services, or a profit accruing by reason of the office. ${ }^{37}$

Lord Justice Atkin states that if the payment was for services rendered during the office or employment, but in fact had not been made until after employment had ceased, it would be subject to tax. I would agree with this proposition. However the statement of $\mathrm{Mr}$. Justice Cattanach is not so limited. I would submit that the following statement of Rowlatt, J., in Foster v. Dewhurst ${ }^{38}$ is the correct statement relating to this problem:

It is quite clear that you can have a payment made after the office has terminated, which nevertheless, having regard to what was said in the secretary's case, Cowan v. Seymour, is taxable; but then it must be, as I understand it, in the nature of a payment made later in respect of a title to payment earned before, that is to say, bringing a past annual profit up to the proper mark by a payment afterwards. That is what I understand that sort of case is. ${ }^{38}$

If therefore the "benefit" arises after the employment ceases, in order for it to be taxable it must relate to the period in which the employment was in fact in existence. I therefore suggest that it is implicit in this statement that the "benefits" must be almost contemporaneous with termination of employment. If this is not so, it would abrogate many of the concepts heretofore established. Would a "benefit" enjoyed by an ex-employee 1 to 5 years after employment had ceased be liable under section 5 ? I think not.

Prizes and awards won in sales contests have been subject to litigation and are currently the subject of much interest. Riddell v. M.N.R.40 held that a trip to Nassau won by Mr. Riddell by virtue of his sales

\footnotetext{
34 Supra, n. 32, at 5262.

35 Ibid.

36 Supra, n. 11.

36 Id., at 379 .

38 (1930), 16 T.C. 623.

30 Id. at 623-624.

4067 D.T.C. 547.
} 
record was a taxable benefit under section 5 (1) (a). The same idea is also found in the case of Rosenburg v. M.N.R.41 in which a cruise paid for by a company which supplied goods to Mr. Roseburg's company was held to be a benefit under both sections 8 (1) and section 5 . However, in a similar case Wasserman v. M.N.R. ${ }^{42}$ a free vacation trip given by a furniture manufacturer to the president of a retail furniture company was counted neither as income nor as a benefit.

The solution to problems of this area is suggested in the recent case of Poirier v. M.N.R. ${ }^{43}$ wherein Mr. Poirier, who was the president of an automobile company which was a franchised Ford dealer, won a trip to the Caribbean Islands.

In this instance the Ford Motor Company of Canada set a certain sales quota for each dealer. Those who reached it were entitled to participate in a drawing which was held. Poirier Automobiles Inc. won the draw and appointed Mr. Poirier to take the trip. Mr. Boisvert in ascertaining that neither section 5 (1) nor 8 (1) applied stated:

I do not believe it necessary to insist further. On the basis of the jurisprudence of this Board we must conclude that the advantage given to the appellant by Ford of Canada did not constitute an income because the origin of the advantage had none of the characteristics of a taxable income. The benefit to the appellant was neither rent, nor interest, or dividend, nor profit, nor salary. It was not the fruit of the tree but rather that of chance.44

He dismisses any application of section $5(1)$ due to the fact that the taxpayer was not employed by Ford of Canada which paid for the trip. It is seen however in both the Rosenburg and Riddell cases ${ }^{45}$ the taxpayers involved were not employees of the payor corporation and yet were found taxable. It is suggested that if the sales incentive program is set up on the basis that the employee involved, instead of getting a trip for his sales prowess, gets his name put into a barrel and by virtue of his name having been drawn from the barrel is awarded the trip, neither section 5 nor section 8 will tax such a benefit. There is earlier jurisprudence supporting this contention. Abraham v. M.N.R..8 established that where a grocer won an automobile in a lottery organized by the wholesalers who supplied his goods the amount received by the grocer in lieu of the automobile was not a taxable benefit.

Turning now to benefits which have been found not to offend section 5. Bursaries, scholarships or grants open to employees as well as nonemployees to which no strings are attached in the form of agreements to work for the granting body are normally not taxed. ${ }^{47}$

The use of a yacht by the president and majority shareholder of a company whose business it was to supply building materials to contractors was held not to constitute a benefit conferred by the company on its employee when it was shown that the appellant had reimbursed the company for the minimal personal use to which he and his family put the boat. ${ }^{48}$

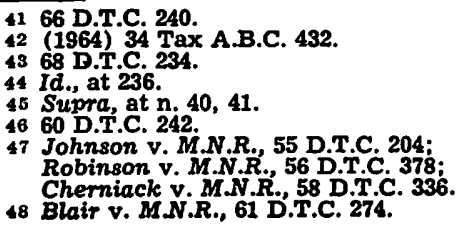


An interest-free loan made by a company to one of its officers was held not to be a "benefit" conferred upon the officer since the company was not compelled by law to demand the payment of interest and the officer was under no obligation to pay it.. ${ }^{49}$

\section{Valuation}

Mr. Fisher in Mansfield v. M.N.R. states:

I have reached this conclusion because in my view the words "other benefits of any kind whatsoever" would have to be read ejusdem generis with the preceding words "board, lodging" and therefore form part of the phrase "the value of board, lodging and other benefits of any kind whatsoever" and indicate a receipt of some benefit in the form other than cash, upon which it is necessary for some valuation to be put. 50

The valuation of benefits is oft-times extremely difficult. The best general statement relating to this area is found in the English case of Wilkins v. Rogerson ${ }^{51}$ wherein an employer arranged with a tailor to supply each of his employees with a suit of clothes as a Christmas present. The cost to the employer of the taxpayer's suit was $£ 1415 \mathrm{~s}$. On appeal the employee conceeded that he had received a taxable benefit but maintained that its value in terms of monies worth was the price for which he could have sold the suit in the open market if he had sold it immediately after he had received it. It was agreed this price was $£ 5$ due to the fact that it should be classified as a second hand suit the moment it was delivered. On appeal the court held that the $£ 5$ value was the measure of the benefit rather than the cost to the employer in providing the suit. The court said in part:

The only controversy was whether he was to pay tax on the cost of that perquisite to his employer or on the value of it to him, and it appears to me that this perquisite is a taxable subject-matter because it is money's worth. It is money's worth because it can be turned into money and, when turned into money, the taxable subject matter is the value received. I cannot, myself, see how it is connected directly with the cost to the employer. ... The taxpayer has to pay on what he gets. Here he has got a good suit. He can realize it only for five pounds. The advantage to him is therefore five pounds. The detriment to his employer has been considerably more but that seems to me to be irrelevent. . . .52

To my knowledge there is no direct Canadian authority on this point. However, I suggest that this attitude is the proper one which should be adopted in valuing the benefit under section 5 . If it is so, many instances will arise where this will be of considerable importance. Assume that a person is given a car, and the car is classified as a benefit. The value of the benefit would be the price of a second hand car. I am told that a new car depreciates approximately $331 / 3 \%$ in its first year, which in most instances would mean the saving of well over one thousand dollars. If an employee wins a trip which is classified as a "benefit" under section 5, what is the value of this benefit? I suggest that if the trip is to Nassau with a group known as The Moose Jaw Chicken Pluckers Cooperative the benefit may be considerably less than the air fare, room and board, etc., to Nassau. It is what the employee could sell this peculiar trip for which would determine the value of the benefit.

49359 v. M.N.R., 56 D.T.C. 475.

5062 D.T.C. 134, 139.

31 (1960), 39 T.C. 344.

52 Id., at 353. 
In relation to this area the case of Zakoora v. M.N.R. ${ }^{53}$ is noteworthy. The appellant drew no salary from the company of which he was the president and controlling shareholder and each year he received the use of a new Cadillac car costing over eight thousand dollars. He drove the automobile chiefly on company business but also to a certain extent for his personal use. The minister assessed him on the ground that the right to use such a car represented a benefit conferred by the company within the meaning of section 5 (1) (a). Mr. Fordham stated:

All that troubles me is the amount of the value placed on the resulting benefit by the respondent. . . . Appellant's auditor estimated the personal use at only $20 \%$ and was not contradicted. All in all and weighing the circumstances it appears to be that $33-1 / 3 \%$ rather than $50 \%$-and there cannot be exactitude in a case of this kind-is the degree of luxury element that more properly attaches to the benefit received by the appellant in each year under review and I so find. ${ }^{54}$

This introduces a rather unusual element in that if a company makes available the use of a luxury car for an employee the benefit would be larger than if they had used a more standard model. Does this mean that if a company houses its executives in a luxuary class hotel there will be an extra benefit? Does the fact that the company executives go to an expensive restaurant rather than the automat imply a benefit? We may someday in the future see the strange sight of a business tycoon roaring to work on his Honda which of course was supplied by his benevolent employer.

Finally, in connection with section 5 , I would refer you to Information Bulletin number 32, a copy of which is set out as appendix 1. It should always be kept in mind that these Information Bulletins are not the law. They are merely attempts by the Department of National Revenue to assist taxpayers in the sense that they reflect departmental policies. If this policy is at variance with the current judicial attitude as reflected in the reported cases, the policy of course must give way to the law as enunicated. You will note that the Department of National Revenue attempts to enumerate specific items which are included as benefits and some which are excluded as being a benefit. The topic enumerated under paragraph 8 "travelling expenses of employees wife" has been dealt with in an excellent article by Mrs. Gwyneth McGregor and Mr. Ronald Robertson ${ }^{55}$ whose opening sentence reads as follows:

The Department of National Revenue is not exactly against marriage, or in favor of sin; but its latest Information Bulletin contains a paragraph which seems to confirm the old tax story that in pre-income tax days men took their secretaries with them on business trips and introduced them as their wives, now they take their wives and introduce them as their secretaries.

The aforementioned article refers to the case of Shambrook v. M.N.R. ${ }^{50}$ and suggests that the decision's importance as a precedent is lessened due to the fact the persons involved were not at arms length. In the recent case of Paton v. M.N.R. ${ }^{5 i}$ the court was dealing with an arms length situation and $\mathrm{Mr}$. Snyder came to the conclusion that there was a benefit conferred upon Mr. Paton due to the fact that Mrs. Paton accompanied him on several business trips.

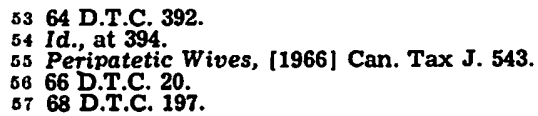


There are however some other sections included in this bulletin which bear some examination, specifically paragraph 4 .

(Gifts) including Christmas gifts-a gift (either in cash or in kind) to an employee is a benefit derived in the course or by virtue of the employment. However, where the value of a Christmas or wedding gift does not exceed twenty-five dollars and where the employer does not claim its cost as an expense in computing his own taxable income the gift is not required to be reported as income of the employee.

I suggest that all gifts made by an employer to an employee are not benefits within the meaning of section 5 . In the well known text The Principles of Income Taxation by J. P. Hannan and A. Farnsworth it is stated at page 21:

A sum of money given by an employer to an employee as a wedding present would ordinarily be regarded as having been given from personal grounds and not as remuneration for services.

In Laidler v. Perry ${ }^{58}$ an employer gave each of his employees a gift voucher for $£ 10$ (approximately thirty dollars) each Christmas. The court held that whether such a gift was a reward or remuneration in return for services and therefore taxable or whether it was merely a gesture of good will at Christmas without regard to services and therefore not taxable was a question of fact. In this instance it was held to be taxable and the pertinent criteria seem to be the propitiousness of the gift. The concept enunciated in Seymour v. Reed has been previously discussed. However Lord Phillimore stated "I do not feel compelled ... to hold that an employer cannot make a solitary gift to his employee without rendering the gift liable to taxation."

Therefore I suggest the concept enunciated in Informations Bulletin No. 32, paragraph 4 is not necessarily valid in law.

I should also like to take issue with the statement found in paragraph 5 which reads:

Holiday trips and other prizes-a free holiday trip or a vacation with expenses paid given by an employer to an employee for long and meritorious service or any prize in cash or in kind in recognition of job performance constitutes a taxable benefit from the employment which should be measured by the cash equivalent.

We have seen from the Poirier case" that the statement "any prize whether in cash or kind in recognition of job performance constitutes a taxable benefit" is not, according to the judicial decisions, correct. Bearing in mind the comments made with respect to valuation one might also take issue with the value measure which is promulgated in paragraph 5 .

Equally important are the types of fact situations which will not as a matter of policy be taxed as income. Such things as employees discounts on merchandise and (paragraph 1) moving expenses (paragraph 9) have wide applications, and sound arguments could be formulated to assess their value to tax. The fact that they will not be taxed is noteworthy. 
SECTION 16

Section 16 (1) reads as follows:

A payment or transfer of property made pursuant to the direction of, or with concurrence of, a taxpayer to some other person for the benefit of the taxpayer or as a benefit that the taxpayer desired to have conferred on the other person shall be included in computing the taxpayer's income to the extent that it would be if the payment or transfer had been made to him.

In effect section 16 (1) construes the payment or transfer of property received by someone else on the taxpayer's behalf or a benefit which the taxpayer wished to confer on another person as a payment received by the taxpayer himself. The section refers to the transfer of "property." Property is defined in very broad terms and includes both real and personal property, tangible and intangible property and a right of any kind. However I suggest that "benefits" as used in this section must be of a tangible nature with an ascertainable value, due to the fact that the "benefit" will be included in computing the taxpayers income. In order for it to be included it must be valued. An interesting commentary with respect to what is meant by benefit as used in section 16 (1) is found in the Exchequer Court judgment in Miller v. M.N.R. ${ }^{61}$ In this case the appellant had been entitled to certain commissions in respect to sales which might be made. The appellant assigned his interest in the future commissions for a lump sum plus a percentage of any payments that may be made in excess of the lump sum. The minister attempted to invoke section 16 (1) to tax in the appellant's hands the percentage payment which might accrue to him. Mr. Justice Thurlow stated:

In my opinion, Section $16(1)$ is intended to cover cases where the taxpayer seeks to avoid receipt of what in his hands would be income by arranging to have the amount received by some other person whom he wishes to benefit or by some other person for his own benefit. The scope of the subsection is not obscure for one does not speak of benefiting a person in the sense of the subsection by making a business contract with him for adequate consideration. ${ }^{62}$

Thus it is seen that if there is a bona fide business transaction no benefit under section 16 (1) will flow. This idea is further strengthened by the pronouncements in Lamb v. M.N.R. ${ }^{63}$ where a professional engineer formed a company to carry on his practice and it was attempted to tax him under section 16 (1) as being the person by whom the fee income was earned. In this case the court held that there was a legitimate business carried on by the company and thus regarded Mr. Lamb simply as an employee of that company with the income being earned by the corporate entity. In contrast to this is the idea expressed in Goldblatt v. M.N.R. ${ }^{64}$ wherein a corporation to which certain commissions were assigned took no active part in the earning of the commissions and indeed was only reactivated after the commissions had been earned. In this instance section 16 (1) was applied in order to tax the individual who in reality was responsible for the earning of the commission.

Section 16 (1) may be used as an adjunct in order to cover areas parallel to those of section 8 . Under section 8 , if a corporation grants a loan to one of its shareholders the amount may be taxed as a dividend. If a taxpayer seeks to avoid the provisions of section 8 by causing a corporation controlled by him to make a loan to his wife instead of

61 [1962] C.T.C. 199.

62 Id., at 212 .

03 (1963), 34 Tax A.B.C. 79.

of [1864] C.T.C. 185. 
himself, in all likelihood he will find himself taxed on the indirect payments as having been made either for his own benefit as or as a benefit he desired to confer on his wife. ${ }^{.5}$

An important limitation relating to section 16 (1) is evidenced in Brabant v. M.N.R. ${ }^{66}$ where it was suggested that equipment was sold at less than fair market value by one company to another in a non-armslength transaction. It was held that it could not be said that the vendors, who were also directors of both the companies, had conferred on the purchasing company a benefit within the meaning of section 16 (1). If anyone was liable under section 16 (1) it would be the vendor company and not its shareholders. Mr. Fisher stated:

Upon consideration of all the evidence and the arguments submitted, and in the absence of any direct evidence from the respondent as to the fair market value of the equipment in March 1955, I am of the opinion that, while it may be open to argument that Brabant Construction \& Supply Co. Ltd. did not receive in March 1955 the full market value for the equipment which it sold to Corrugated Pipe, nevertheless it has not been brought home to the appellant herein, either as a shareholder of Brabant Construction or as a shareohlder of Corrugated Pipe, that there was a transfer of "things" made, at her direction or with her concurrence, to some other person for her benefit, or as benefit which she desired to have conferred on the other person to bring the transaction within the provisions of either subsection (1) of section 16, ss. (1) of section 8 or paragraph (a) of section 5 of the Income Tax Act. If there was any benefit conferred, it seems to me that the benefit would have to be considered to have been conferred by Brabant Construction upon Corrugated Pipe, and accordingly that, if any taxpayer is liable under the provisions of subsection (1) of section 16, it would be Brabant Construction \& Supply Co. Ltd. itself, and not the shareholder of that company such as the appellant herein. ${ }^{67}$

While the Income Tax Act has been amended subsequent to this case I suggest that section 16 (1) will not tax the individuals even in the case of a transfer between companies who are controlled by the same shareholders. In other words the corporate entity will be recognized. It is therefore not difficult to conceive many factual situations in which advantage may be taken of this interpretation. Perhaps one may sympathise with Mr. Justice Dumoulin in a more recent case ${ }^{88}$ in which the concept of "benefit" was not a direct issue, but in dealing with section 16 (1) he stated: "Before delving into examination of this none too clear provision of the law ..." ${ }^{\circ 9}$ he continued, "What should be construed as the more plausible meaning and intent of this none too limpid text of our fiscal law? After some hesitation, I take the view that a literal interpretation is the truer course."70 Assuming the literal interpretation of benefits as appearing in this subsection, I suggest that the observations offered earlier in connection with section 5 (1) (a) would have equal application in attempting to analyze a peculiar fact situation in relation to the possible application of section 16 (1).

\section{APPENDIX 1-INFORMATION BULLETIN 32}

The purpose of this Bulletin is to enumerate various common types of "fringe benefits" and to indicate whether or not the value thereof should be included in income. It has been divided into two parts as follows:

65 Reininger v. M.N.R. (1958), 20 Tax A.B.C. 242.

6861 D.T.C. 429.

67 M.N.R. v. Bronfman, 65 D.T.C. 5240.

69 Id., at 5236 .

70 Id., at 5238 . 
Part A-Amounts to be included in income

Part B-Amounts not to be included in income

In those cases where the value should be included, the employer should determine the value, or make a reasonable estimate of it when it cannot be precisely determined, and include that value in the box provided on form T4 under the headings "Total Earnings Before Deductions" and also in the box headed "Taxable Allowances and Benefits". The information herein refers to cases where there is only an employeremployee relationship and does not necessarily apply if the employee is also a shareholder or a relative of the owner of the business.

\section{PART A-AMOUNTS TO BE INCLUDED IN INCOME}

1. Board and lodging-The Income Tax specifically refers to board and lodging as a benefit derived from the employment. This includes board and lodging regularly furnished as a perquisite of the employment, as is common, for example, in the case of hotel employees and domestic and farm help. Normally the value placed on this benefit should reasonably approximate the lesser of fair market value or the cost to the employer.

Where this perquisite is not furnished free, but at an unreasonably low rate, there is a taxable benefit equal to the difference between the amount charged the employee and a reasonable valuation of the board and lodging supplied.

2. Rent-free and low-rent housing-Where an employer provides a house, apartment or similar accommodation to an employee rent-free or for a rental that is lower than the employee would have to pay someone else for similar accommodation, the employee receives a taxable benefit. It is the responsibility of the employer to reasonably estimate the amount of such a benefit.

3. Personal use of employer's automobile-Where an employee is permitted to make personal use of an automobile maintained by his employer he should include in income the value of the benefit to him arising from the personal use made of the automobile. Normally the value of that benefit is that proportion of total operating costs of the automobile that his personal use bears to its total use in the year. For this purpose, "operating costs" include such things as licenses, insurance, repairs, gasoline, oil, servicing charges and rentals paid that are dependent on miles of use. However, operating costs in respect of an automobile used substantially for business purposes need not include capital cost allowances or rentals not dependent on miles of use, such as are common when the employer's practice is to rent a fleet of cars for a long term.

4. Gifts (including Christmas gifts)-A gift (either in cash or in kind) to an employee is a benefit derived in the course of or by virtue of the employment. However where the value of a Christmas or wedding gift does not exceed $\$ 25$ and where the employer does not claim its cost as an expense in computing his own taxable income the gift is not required to be reported as income of the employee.

5. Holiday trips and other prizes-A free holiday trip or a vacation with expenses paid given by an employer to an employee for long or 
meritorious service, or any prize, whether in cash or in kind, in recognition of job performance, constitutes a taxable benfeit from the employment which should be measured by the cash equivalent.

6. Premiums under provincial hospitalization plans and provincial medical services plans.-Where an employer has paid the premiums, or a portion thereof, on behalf of an employee under any Provincial Hospitalization Plan, the Medicare Plan of Saskatchewan, the Ontario Medical Services Insurance Plan, the British Columbia Medical Plan, or except in the case of a "group standard contract", the Alberta Health Program, the amounts paid during the year must be included in the employee's income.

7. Tuition fees.-Where an employer has paid tuition fees on behalf of an employee or has reimbursed an employee, in whole or in part, for tuition fees paid by the employee personally, the amount paid should be reported as income of the employee for the year in which the payment was made. Amounts so included will, in most cases, be deductible by the employee as tuition fees but not necessarily in the same taxation year.

8. Travelling expenses of employee's wife.-Where an employee's wife accompanies him on a business trip and the employer either pays her travelling expenses or reimburses the employee or his wife for them, the payment or reimbursement should be reported as a taxable benefit to the employee, even though the wife participates in ancillary social activities or makes some incidental contribution to the business aspects of the trip.

\section{PART B-AMOUNTS NOT TO BE INCLUDED IN INCOME}

1. Discounts on merchandise.-This refers to a percentage discount which is commonly extended to employees in merchandising businesses. The benefits that may be derived by an employee from exercising such a privilege are not regarded as taxable benefits. This does not extend to an extraordinary arrangement that may be made with a particular employee or select group of employees nor to an arrangement by which an employee is permitted to purchase merchandise (other than old or soiled merchandise) for less than the employer's cost.

2. Transportation passes.-Where, in the transportation industry, an employee is given the privilege of a free pass for himself and his family on vehicles operated by his employer, he is not regarded as receiving a taxable benefit.

3. Subsidized meals.-Employers who are not ordinarily purveyors sometimes set up canteens or lunch rooms at which employees may purchase noon meals at low prices. Similar arrangements are also made for making all meals available at low prices in remote areas. In these circumstances, the employees are not regarded as being in receipt of taxable benefits unless the price charged is nominal.

4. Uniforms and special clothing.-Where an employee is supplied with a distinctive uniform which he is required to wear while carrying out the duties of his employment or where he is provided with special clothing designed to protect him from the peculiar hazards of the employment, he is not regarded as getting a taxable benefit therefrom. 
5. Subsidized school services.-In the case of employment in remote or unorganized areas employers frequently assume, initially at least, responsibility for essential community services of a kind normally borne by a municipal organization. Where, in such a situation, the employer provides free or subsidizes school services for children of the employees, a taxable benefit is not thereby deemed to accrue to the employees by virtue of their employment. This does not extend to a payment made by the employer, on behalf of an employee, of school fees or other direct charges otherwise payable by an employee consequent upon the employee's dependants attending a school or university. The latter payments are taxable benefits.

6. Transportation to the job.-Employers sometimes find it expedient to provide vehicles for transporting their employees from pickup points to the location of the employment at which, for security or other reasons, public and private vehicles are not welcome or not practical. In these circumstances the employees are not regarded as in receipt of a taxable benefit.

7. Interest-free loans.-Where an employer lends money to an employee without interest, or at an unusually low rate of interest, he is not regarded as conferring a taxable benefit on the employee within the meaning of Section 5 of the Act. However, if the employer is a corporation and the employee is a shareholder of the corporation, Section 8 of the Act may apply.

8. Recreational facilities.-Normally where recreational facilities are maintained by the employer and made available for use of the employees generally, free of charge or upon payment of a nominal fee, the value of any benefit derived by an employee from taking advantage of such a privilege is not taxable. However, if the employee is furnished with board or lodging, as for example where a summer hotel or hunting lodge is maintained by the employer, the value of board and lodging received by the employee must be included in his income.

Similarly, where the employer pays the fees required for some employees to be members of a social or athletic club where it is to the employer's advantage for the employee to be a member of the club, the employee is not deemed to have received a taxable benefit.

9. Removal expenses.-Where an employer reimburses an employee for the expenses incurred by the latter in moving himself, his family and his household effects either because the employee has been transferred from one establishment of the employer to another or because the employee has accepted employment at a place other than that where his former home was located, this reimbursement is not considered as conferring a benefit on the employee.

In addition, where the employer pays the expense of moving an employee and his household out of a remote place at the termination of his employment at such a place, there will be no taxable benefit imputed.

In ordinary circumstances, if an employer reimburses his employee for a loss suffered by the latter when he sells his house because he has been required by the employer to move to another locality, or because he has retired from the employment in a remote area, the amount so reimbursed will not be income of the employee if it was not greater than the actual loss to the employee, calculated as the amount by which 
the cost of the house to him exceeds the net selling price he received for it. Should the employer buy the house from the employee, no amount will be included in the employee's income if the price paid by the employer does not exceed the greater of the cost of the house to the employee or the current fair market value of comparable houses in the same area.

General-Most of the commoner "fringe benefits" have been included in the foregoing comments, where they have been classified either as taxable benefits or non-taxable privileges. In the second group there may well be a point beyond which the "privilege" concept is no longer valid, i.e. the advantage to the employee no longer bears a casual or traditional relationship to the employment but has become a disguised form of extra remuneration. 